\title{
The Shift to Online Education Paradigm due to COVID-19: A Study of Student's Behavior in UAE Universities Environment
}

\author{
Liaqat Ali
}

\begin{abstract}
The shift to an online education paradigm has been dramatically seen in educational systems and universities due to COVID-19 across the world, especially in United Arab Emirates. The emergence of COVID-19 forced educational institutions to divert all strategies from physical to online platforms for the safety of students, instructors and all the other staff members. However, this is not the case in educational institutions only because other governmental and non-governmental institutions are affected in the same way around the world. The objective of this research is to understand the behavior of students due to a sudden shift towards an online education experience in university environment and gauge their preference either on physical or online education system for the future. The research collected data through an online questionnaire from 210 undergraduate university students which further helped the researcher to draw the discussion and conclusion. The research proves that a high majority of students are willing to change from physical education to an online platforms and they believe that they can perform well by the adoption of this new platform of online education system. The research recommendations are helpful for the educational policy developers.
\end{abstract}

Index Terms-COVID-19, Corona, education, e-learning, universities, UAE.

\section{INTRODUCTION}

The outbreak of COVID-19 in United Arab Emirates along with other countries in the world may cause significant disruption to the provision of education, training and mobility opportunities for learners, teachers and educators across the United Arab Emirates (UAE). COVID-19 (Corona Virus), started in the city of Wuhan China, is one of the hot topics in today's world and has forced the world to think about new paradigms in all fields of life.

In December 2019, the World Health Organization received a report of a group of pneumonia cases from an unknown source in Wuhan, China. This would later be known as the Coronavirus pandemic.

It was classed as a Public Health Emergency of International Concern on 30th January by the World Health Organization and would soon go on to be classified as a pandemic on 11 March [1], [2]. As of 1 May 2020, there have been more than 3 million cases reported in 213 different countries and territories, and the infamous Coronavirus has

Manuscript received May 7, 2020; revised December 23, 2020.

Liaqat Ali is with the Department of Information Technology, College of Engineering and Information Technology, University of Science and Technology of Fujairah, P.O. Box: 2202, Fujairah, United Arab Emirates (e-mail: liaqat22@gmail.com). taken more than 200,000 lives [3]. COVID-19 continues to rampage globally and has resulted in a mass closure of facilities.

Due to the COVID-19 pandemic, educational systems worldwide have been affected, causing closure in many schools, colleges, and universities. According to UNESCO, 186 countries have closed educational facilities nationwide, thus impacting over 90 percent of global learners: about 1.3 billion students [4]. Due to this closure, teachers, as well as students, have suffered. Many teachers have been forced to halt classes and instead proceed with online classes, where the student joins a call session and the subject is taught virtually. As well as physical classes, many physical exams around the world have also ceased. The ceasing of physical exams has either meant that students must participate in online examinations to be awarded grades. Due to the closure of many physical educational systems, education ministries globally are questioning the necessity of an online educational system. The question of whether online education is more efficient than physical has derived as a result of these closures. Whilst this also derives the question of efficiency, the legitimacy of online examinations is also being questioned: whether these examinations can be conducted without students using any unfair actions.

\section{RESEARCH BACKGROUND}

An online classroom provides education to students through the internet. This can be done via call sessions where a qualified teacher communicates with students, or students can be provided with learning material to complete at home. Online education allows educational facilities to reduce costs and increase flexibility. Research has shown that teachers are generally more satisfied when they have the ability to be more flexible in their teaching environment [5]. It also provides more comfort thus resulting in less pressure on both students and teachers alike. The pivot to online education has helped teachers use methods to cope with challenges they may not have been able to deal with in-person [6]. In contrast, online education lacks in accreditation and discipline. This can result in students not being as focused and producing work with inferior quality compared to physical education. Online education can also restrict creative students. Students who study art and music may be limited to produce work with the equipment they have at home. While physical education is more costly than online education, it provides students with discipline, accreditation, and creativity. However, due to there being a location, some students may find it easier to 
attend online classes [7].

Due to the COVID-19 outbreak, the education system across the world has turned tides and is now relying on an online curriculum and teaching system rather than the traditional, in-house method of teaching. The immediate closure of schools and campuses across many parts of the world has made it vastly more apparent that the delivery of online courses become a necessity. This pandemic has made it clear that the education system is one that has been disrupted the most across the globe [8]. In order to keep knowledge retention steady within students across both lower levels of education and further education, the use of e-learning and remote teaching has shown to be imperative [9]. An e-learning environment refers to that which students use online and internet based resources to access the curriculum [10]. An effective online learning environment promotes student engagement with both faculty and peers [11]. As well as this, online learning can also increase productivity in a time where many people are quarantined and locked down inside their homes for the majority of the day [9]. The importance of online education is further exemplified when you take into account the social aspect of it [9]. Communicating and collaborating with peers through e-learning can help boost mental levels and avoid strain/depression due to isolation by engaging with your classroom and professors/teachers [9].

Online education was already on the rise in the year 2019, and with the COVID-19 situation and the majority of the world switching to a digital format, it has become solidified that there is a place for online education in the prospective. Multiple initiatives across the world have taken part in providing high quality online education [12]. With no doubt, technology has become much more versatile and much more commercially available throughout the last decade [13]. This gives students all over the world to build on their education and further enhance their future endeavours and prospects [13]. Online education holds revolutionary potential as online learning is the pinnacle of educational accessibility [14]. It is possible for student learning, achievement and motivation to be just as good as or even better than that in the traditional [15]. Students themselves believe that it increases their motivation and helps develop their critical thinking [16] In the future online courses will play a huge role in the longevity of universities and courses as it will open the doors of further education to those who currently are hindered by time and other motives [17]. Being able to effectively manage lesson time is a critical part of the online learning experience and within the online learning environment [18]. If online learning does take off, then it becomes significantly easier for universities and schools to enrol students as physical barriers such as classroom capacities are completely taken out from consideration [17]. As of current, the focus is on integration of online studies rather than replacement, however as more and more people choose to take benefit of this system, it becomes debatable that online education replaces physical education as the standard.

\section{COVID-19, ONLINE EDUCATION AND UNITED ARAB EMIRATES}

Educational institutions along with other industries such as transport, retails and many more are highly affected by the way they conduct their day to day businesses. The first confirmed case of the pandemic of coronavirus disease 2019 in the United Arab Emirates was announced on the $29^{\text {th }}$ January 2020. UAE was the first country in the Middle East to report a confirmed case [19] and since that time the rulers of UAE have taken extreme measures for the safety of the public. These measures effected almost every institute and individual directly or indirectly. However, educational institutions are one of the most to be discussed.

In midst of the COVID-19 outbreak, the UAE have taken drastic measures in order to prevent student education coming to a standstill. Through the use of e-learning technologies such as google classroom and Microsoft teams being put into use throughout the UAE, education and regular classes for both lower and further education have steadily and stably continued ever since the closure of schools throughout the gulf region [20]. In modern learning environments, the emphasis of learning is on the student, therefore the students are given the opportunity to use information technology as a tool to much greater lengths in e-learning than compared to traditional methods [21]. The communication revolution has allowed for new communication tools to be used in the higher education sector [22]. The UAE's Telecommunication Regulatory Authority (TRA) have added the additional set of applications which are Cisco WebEx, Avaya Spaces, Blue-Jeans and Slack. These applications are available on all of the UAE's networks on an exceptional basis and until further notice, the regulator said in a statement [23]. The higher education and advanced skills ministry of UAE has also made it apparent that universities are banned from issuing academic warnings and dismissing students due to the coronavirus outbreak. However, most institutions of higher education have been given the green-light to put into place any procedures they deem fit and necessary for the guarantee of educational continuation [24].

As the use of online education and remote learning only increases the longer the COVID-19 pandemic continues to transpire, issues are brought up against many scholars and educators. These concerns bring up concepts such as the validity and the reliability of online formative assessment and whether or not it holds the same validation and relation to that of physical, in-house assessment basis [25]. Ethical considerations in the use of learning analytics are being brought up frequently in the e-learning field [26]. There are varying attitudes in regards to e-learning as some scholars believe it comes with the same level of effectiveness as traditional learning, and others arguing that it does not. However many reviews tend to highlight it as an effective means on education [18]. Students will be encouraged to believe that e-learning is more useful if they see an increase in their level of performance [27]. Potential use of an online assessment format may encourage the student to use computer-based instruments and other sources of possible influence. Different approaches have been used by higher education institutions to limit the effect of student plagiarism in assessments [28]. This makes it difficult for educators and scholars to take use of an online assessment format and makes them less likely to recommend and integrate it within 
their own course [29]. This is solely due to the fact that an online format can be manipulated and taken advantage of by the student, significantly more than an offline, physical examination. Since the adoption of online education streams the experience has been both challenging and rewarding. Coronavirus Forces $\$ 600$ Billion higher education industry online [30].

There is an unprecedented and dramatic increase in remote work happening around the world due to circumstances resulting from COVID-19. CISCO WebEx and Zoom are widely used by the users for the purpose of education and online meetings especially in the United Arab Emirates. Other applications provide remote work facility as well. Using these web software, social presence in enhanced in the online learning environment, which is a key factor in e-learning as studies have showed the greater the social interaction, the greater the quality of learning and deeper interaction [31]. According to World Economic Forum, data collected from Priori-Data, global downloads of Skype, House-party and Zoom each surged by more than 100 percent in March 2020, as shown in Fig. 1 below, source [32].

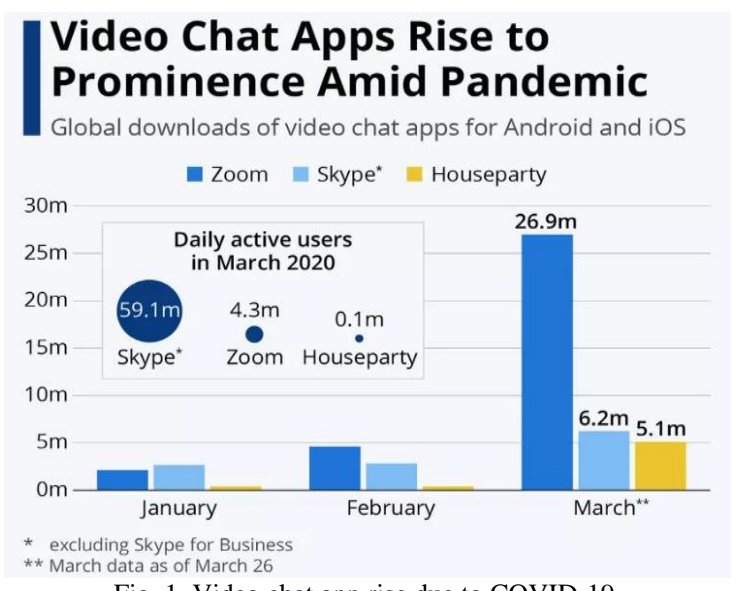

Fig. 1. Video chat app rise due to COVID-19.

\section{RESEARCH METHODOLOGY}

For the purpose of primary data collection, an online survey was developed to understand student behavior. The data is collected through a close-ended questionnaire containing 20 questions from university students across the United Arab Emirates. It is difficult to measure the number of students from which universities in UAE participated in the survey of this research because majority of the students used their personal email addresses. However, following are the confirmed university names where student's participation is noticed through their email addresses. These universities are:

- Ajman University UAE

- Higher Colleges of Technology UAE

- United Arab Emirates University UAE

- American University of Sharjah UAE

- University of Science and Technology of Fujairah UAE In addition, Ministry of Education, UAE also participated in the survey of this research. The answers collected from 210 respondents of the survey questions are gauged on the scale of Strongly Agree, Agree, Neutral, Disagree, and Strongly Disagree. The responses were collected during the period of Sunday 26 March 2020 - Friday 01 May 2020. Table I, the next section 5 provides the analysis and the questions asked in the survey of this research.

\section{FINDINGS AND DATA ANALYSIS}

The data collected through the closed ended online questionnaire; it was found that in total 210 undergraduate students participated in the survey of this research. This section analyzed the results of the data through the help of graph and table.

\section{A. Gender of Survey Respondents}

Both male and female students showed high interest in the survey of this research. The data is collected from the university students of undergraduate programs. The majority of participants within the survey were female $(80.5 \%)$ whereas only $17.6 \%$ were male and only $1.9 \%$ chose not to say their gender. This shows that the female demographic was more inclined to responding to the survey than the male demographic as shown in Fig. 2 below.

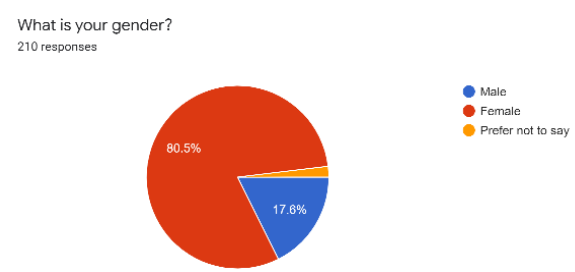

Fig. 2. Gender of respondents.

\section{B. Data Analysis and Findings}

Table I below shows the data collected through the survey of this research.

TABLE I: DATA FINDINGS AND ANALYSIS

\begin{tabular}{|c|c|c|c|c|c|c|}
\hline $\begin{array}{l}\text { S. } \\
\text { No. }\end{array}$ & Question & $\begin{array}{l}\text { Strongly } \\
\text { Agree }\end{array}$ & Agree & Neutral & Disagree & $\begin{array}{l}\text { Strongly } \\
\text { Disagree }\end{array}$ \\
\hline 1 & $\begin{array}{l}\text { I like the environment of teaching and learning compared to physical education in } \\
\text { university. }\end{array}$ & $20 \%$ & $40 \%$ & $21 \%$ & $11 \%$ & $8.1 \%$ \\
\hline 2 & It is easier to manage when learning online than physical education in university. & $18.1 \%$ & $27.1 \%$ & $25.2 \%$ & $16.2 \%$ & $13.3 \%$ \\
\hline 3 & Online education helps to save time and cost in the learning process. & $28.1 \%$ & $41 \%$ & $17.6 \%$ & $6.2 \%$ & $7.1 \%$ \\
\hline 4 & Online education is more beneficial than physical education in university. & $10.5 \%$ & $17.6 \%$ & $28.1 \%$ & $27.6 \%$ & $16.2 \%$ \\
\hline 5 & Online education provides flexibility in the process of learning. & $18.1 \%$ & $34.3 \%$ & $24.8 \%$ & $14.8 \%$ & $8.1 \%$ \\
\hline 6 & $\begin{array}{l}\text { The assessment process of online education is more appropriate than the physical } \\
\text { education in university. }\end{array}$ & $13.8 \%$ & $26.2 \%$ & $31.4 \%$ & $16.7 \%$ & $11.9 \%$ \\
\hline 7 & I believe I can perform well during exam through online systems & $19 \%$ & $30 \%$ & $22.4 \%$ & $13.3 \%$ & $15.2 \%$ \\
\hline 8 & $\begin{array}{l}\text { Qualification achieved through online education must be given the same weight of } \\
\text { physical education. }\end{array}$ & $15.7 \%$ & $37.6 \%$ & $21.4 \%$ & $17.6 \%$ & $7.6 \%$ \\
\hline 9 & $\begin{array}{l}\text { The online format of education is completely appropriate for the course/programme } \\
\text { I am enrolled in. }\end{array}$ & $16.7 \%$ & $27.6 \%$ & $38.6 \%$ & $11.9 \%$ & $5.2 \%$ \\
\hline 10 & The online education system increased the quality of my learning. & $13.8 \%$ & $28.6 \%$ & $24.3 \%$ & $24.8 \%$ & $8.6 \%$ \\
\hline
\end{tabular}




\begin{tabular}{|c|c|c|c|c|c|c|}
\hline 11 & $\begin{array}{l}\text { Online instruction is an effective means to deliver the content of my } \\
\text { course/programme. }\end{array}$ & $11.4 \%$ & $31.9 \%$ & $32.9 \%$ & $17.1 \%$ & $6.7 \%$ \\
\hline 12 & I myself feel very comfortable for the online education system. & $18.1 \%$ & $35.7 \%$ & $20.5 \%$ & $14.8 \%$ & $11 \%$ \\
\hline 13 & $\begin{array}{l}\text { The online education systems is more helpful in managing my work and family } \\
\text { activities. }\end{array}$ & $25.7 \%$ & $37.6 \%$ & $19.5 \%$ & $10.5 \%$ & $6.7 \%$ \\
\hline 14 & $\begin{array}{l}\text { I found more interaction with my instructors during the course of online learning } \\
\text { process }\end{array}$ & $15.2 \%$ & $22.4 \%$ & $29.5 \%$ & $21 \%$ & $11.9 \%$ \\
\hline 15 & $\begin{array}{l}\text { The instructors are more concerned about the students in online education than } \\
\text { physical education in university }\end{array}$ & $14.8 \%$ & $31.4 \%$ & $28.1 \%$ & $19 \%$ & $6.7 \%$ \\
\hline 16 & $\begin{array}{l}\text { In online education, the instructor quickly and efficiently responds to student's } \\
\text { needs. }\end{array}$ & $17.6 \%$ & $32.4 \%$ & $28.1 \%$ & $16.2 \%$ & $5.7 \%$ \\
\hline 17 & $\begin{array}{l}\text { The instructor consistently provides good online lectures with several examples and } \\
\text { discussions compare to physical education in university. }\end{array}$ & $14.8 \%$ & $33.3 \%$ & $31.9 \%$ & $14.3 \%$ & $5.7 \%$ \\
\hline 18 & $\begin{array}{l}\text { Online education helps to manage my attendance of classes effectively than the } \\
\text { physical attendance in university }\end{array}$ & $25.7 \%$ & $39.5 \%$ & $17.1 \%$ & $14.3 \%$ & $3.3 \%$ \\
\hline 19 & $\begin{array}{l}\text { The overall accessibility and availability of the online education is far better than } \\
\text { physical education in university. }\end{array}$ & $17.6 \%$ & $27.1 \%$ & $25.7 \%$ & $19.5 \%$ & $10 \%$ \\
\hline 20 & I believe online learning and education is the only future for learners and teachers. & $13.8 \%$ & $31 \%$ & $24.8 \%$ & $17.1 \%$ & $13.3 \%$ \\
\hline
\end{tabular}

\section{DisCUSSION AND CONCLUSION}

Online education and e-learning have always been an important part of the education system, as they come with many benefits that physical education simply cannot provide. E-learning is able to provide much flexibility in the learning experience as students are able to access materials according to their needs [33]. This is advantageous as allows the individual to work on their own level [34]. Its tremendous growth over the last decade, and as more people become accustom to using technology for education is a clear sign that it has a much more impactful future. As the internet and World Wide Web only become more accessible on a slew of internet capable devices, e-learning assets and other education tools are seeming to become even more important than textbooks and libraries, as they create a much more diverse methodology of learning than what the traditional education medium offers [35]. E-learning will be in the mainstream of education in the future as the advantages it holds greatly benefits both the learner and the institution [36] One of the many reasons why people are seeming to acknowledge the importance of online education is due to the fact that online education gets students set on their career path faster than physical education [35]. This is because when variables and restrictions such as the location of the university and the excess amount of expenses that come along with it are taken away, online education allows students from all over the globe to take part in a certain curriculum and the limiting factors of their geographic is completely removed [35]. This allows information to reach a larger pool of students and therefore harbouring larger advances in a diverse multitude of professions and careers [35]. However, there are growing concerns that long screen-time exposure could be a deterrent factor in online education being perused [37]. Moreover, interference with technology and tech issues caused on either end may perceive e-learning as a hindrance rather than a useful tool [38].

As per the survey conducted of this research, the overall percentage of participants agreed with the statement whilst the second most popular choice was to go with strongly agree that the environment of teaching and learning is better online than it was on campus. This shows that the majority of students prefer learning and being taught online rather than physically in person. The majority of students chose to agree and strongly agreed that it is easier to manage learning online than physical education. Although a very small proportion disagrees, it is clear that the majority of students have a much easier time managing their learning when using online education. Also, the majority of survey respondents chose to agree, while a significant portion said they strongly agree and believe that online education saves them both time and cost and therefore as a result most likely prefer online education compared to physical as saving on costs can be considered as one of the most important benefits for students.

Most participants were neutral towards the statement that online education is more beneficial than physical education while another significant amount disagrees. This implies that most students either believe that physical education is more beneficial than online or that they hold the same value as neutral opinions can go both ways in this case. Most participants of the survey conducted are agree and believe that online education provides more flexibility whilst a large proportion believe it offers the same flexibility as physical education does. Most participants of the survey were found neutral and a significant amount was found to be inclined to believe that the assessment process was either more appropriate or the same, compared to that of physical education for them. The majority of participants chose to agree whilst some decided to keep their opinion neutral that they can perform better during online examinations rather than class-based examinations as they are possibly inclined to feeling more comfortable during online examinations process. The majority of participants feel that qualifications achieved through online education should be given the same weight as those achieved through physical. Most participants were found neutral, followed by many a significant majority agreeing towards the online format of education and the others were mostly in agreement that it was appropriate.

Further, majority of the survey participants agreed and felt that online education system increased the quality of learning, however, there were still many who felt it wither did not affect the quality or decreased the quality. Also majority of students felt that online instructions were more beneficial than or just as beneficial as physical instructions are. Majority of the students as per the survey were also found comfortable in the online education system compared to being on campus and learning physically. A vast number of participants found that online education systems is more helpful in managing their work and family activities. 
Students also found the same amount of interaction during the online learning process with their instructors like physical education and they feel that instructors are more concerned or show the same concern as they do in physical education in the university. Also, most participants mainly believed that instructors were quick and efficient to respond to student needs during the process of online teaching and learning. E-learning comes with advantages, such as a higher pool of students being able to enroll in the school and giving a further range of opportunities to those students that face demographical issues [18]. Further, majority of the survey students felt that instructors were providing good online lectures compared to physical education in universities. Moreover, student enrolment and satisfaction is linked to student success, teacher involvement and student retention in an online learning program [39].

A vast number of participants were inclined to agree that online education helped manage their attendance more effectively than physical attendance in universities. Also, most participant are in agreement of the statement that the overall accessibility and availability of the online education is far better than physical education in university or have a neutral opinion of it. Most participants agreed, however, a significant amount was neutral that online education is the only future for learners and teachers.

Similar to other countries around the world, the UAE has asked teacher and staff to work from home and enforce a remote learning system [40]. Certain schools have issued students education packs with e-learning tools that they can use during independent learning in lockdown [40].

\section{RECOMMENDATIONS}

In spite of the COVID-19 situation, it has been made clear that online education is a possibility that should be considered to either be put in line with physical education or replace it. Benefits such as the flexibility of online education, the comfort that it brings to students, self and manageable paced learning and the cost savings, cannot be ignored and overlooked. Its rise in popularity over the last decade only shows that more students would agree with the implementation of online education and also benefit from it. Therefore, implementation of various smart universities by the government would benefit all stakeholders. Not only will these smart universities be cost effective and more profitable than traditional campus-based universities, but they will also be more beneficial for students as a wider range of courses will be available compared to traditional universities and therefore advance many different career paths. This would intern benefit staff such as teachers as more teachers would be given jobs in order to facilitate the vast demand and influx of students.

An appropriate form of assessment should be designed for students participating in online education. This will provide such students with a robust and reliable area to perform their assessments. As per the survey, about a quarter of the participants chose to either strongly disagree or to disagree that the form of assessment within online education is more appropriate than that of physical education. This shows that while the assessment form is useable it can still be updated to allow all students to feel comfortable when performing online exams. When designing this form of examination, designers should take specific note to whether the program is reliable and safe, whilst also ensuring its fairness among all students.

Students should be able to choose whether they would like to enrol in an online or physical course. Physical courses can be more expensive than an online course and may also provide less flexibility. For example, students who live far from the university have to pay for transport or a boarding facility. If online education was universally available for students, it would allow them to receive and attend lectures at any location. The idea of online education is more flexible can also be observed in the survey as the majority of the participants agreed that online education allows them to balance work and family activities.

To conclude, the ministry of education in United Arab Emirates should most defiantly review their educational policies in order to implement an online education system. The underlying advantages and various benefits to multiple stakeholders should not be ignored by the ministry of education and should rather be looked into being implemented as effectively and efficiently as possible. This will help evolve the education system into further reaches and make learning all the more accessible for a multitude of students.

\section{CONFLICT OF INTEREST}

The authors declare no conflict of interest.

\section{REFERENCES}

[1] BBC. (2020). Coronavirus confirmed as pandemic by World Health Organization. Corona Virus Pandemic. [Online]. Available: https://www.bbc.co.uk/news/world-51839944

[2] J. Gallagher "Preparing other countries, Corona virus pandemic by World Health Organization," 2020.

[3] WHO. (2020). Coronavirus disease (COVID-19) pandemic, World Health Organization. [Online]. Available: https://www.who.int/emergencies/diseases/novel-coronavirus-2019

[4] UNESCO. (2020). COVID-19 Educational disruption and response, Impact on education. [Online]. Available: https://en.unesco.org/covid19/educationresponse

[5] K. Anderson, "5 key reason why elearning is essential and not overrated, elearning industry in French," 2017.

[6] A. Murphy, "The future of online learning," Online-Studies, 2019

[7] S. E. Baum, "Distance learning during Corona Virus: How it works, benefits and challenges," Teen-Vogue, 2020.

[8] W. Abbas, "Covid-19: UAE's TRA adds more apps for distance learning," Khaleej Times Education, Dubai UAE, 2020.

[9] Unknown. (2020). Corona Virus, Al-Arabia. [Online]. Available: https://english.alarabiya.net/en/coronavirus

[10] J. Hechinger and J. Lorin, Bloomberg BusinessWeek, April 2020.

[11] Unknown. (2020). The value and benefits of online education. Digital Skills Education. [Online]. Available: https://digitalmarketinginstitute.com/en-gb/blog/the-value-and-import ance-of-online-learning

[12] H. Karishma and K. H. Nandkeolyar, "Coronavirus in UAE: Schools to stop all meets," Gulf News Education, United Arab Emirates, 2020.

[13] C. Guan et al., "E-learning in higher education for adult learners in Singapore," International Journal of Information and Education Technology, vol. 5, no. 5, May 2015

[14] A. Després-Bedward, T. L. Avery, and K. Phirangee, "Student perspectives on the role of the instructor in face-to-face and online learning," International Journal of Information and Education Technology, vol. 8, no. 10, October 2018.

[15] H. M. Lin, W. J. Chen, and S. F. Nien, "The study of achievement and motivation by e-learning - A case study," International Journal of Information and Education Technology, vol. 4, no. 5, October 2014. 
[16] M. Axelsen, P. Redmond, E. Heinrich, and M. Henderson, "The evolving field of learning analytics research in higher education: From data analysis to theory generation, an agenda for future research," Australasian Journal of Educational Technology, vol. 36, no. 2, pp. 1-7, 2020.

[17] J. Carpenter, "Digital tools in the classroom: Measuring the effectiveness," Current Issues in Emerging eLearning, vol. 6, issue 1, article 3, 2019.

[18] N. Johnson, G. Veletsianos, and J. Seaman, "U.S. faculty and administrators' experiences and approaches in the early weeks of the COVID-19 pandemic," Online Learning, vol. 24, no. 2, pp. 6-21, 2020.

[19] I. Garcia, "e-leadership: A bibliometric analysis," International Journal of Advanced Corporate Learning (iJAC), ISSN: 1867-5565, vol. 13, no. 1, 2020.

[20] R. N. Kibuku, D. O. Ochieng, and A. N. Wausi, "E-learning challenges faced by universities in Kenya: A literature review," The Electronic Journal of e-Learning, vol. 18, no. 2, pp. 150-161, 2020.

[21] Priori-Data. (2020). The video apps we're downloading amid the coronavirus pandemic. Word Economic Forum. [Online]. Available: https://www.weforum.org/agenda/2020/03/infographic-apps-pandemi c-technology-data-coronavirus-covid19-tech/

[22] C. J. Tanis, "The seven principles of online learning: Feedback from faculty and alumni on its importance for teaching and learning," Research in Learning Technology, 2020, vol. 28, p. 2319.

[23] J. W. Gikandi, D. Morrowa, and N. E. Davis, "Online formative assessment in higher education: A review of the literature," Computers \& Education, vol. 57, issue 4, December 2011, pp. 2333-2351, Science Direct, Elsevier.

[24] A. J. M. Karkar, H. K. Fatlawi, and A. A. Al-Jobouri, "Highlighting E-learning adoption, challenges using data analysis techniques: University of Kufa as a case study," The Electronic Journal of e-Learning, vol. 18, no. 2, pp. 136-149, 2020.

[25] R. Holbeck, S. Greenberger et al., "Reporting plagiarism in the online classroom," MERLOT Journal of Online Learning and Teaching, vol. 11 , no. 2, June 2015.

[26] Unknown. (2020). Connecting digitally - Coronavirus advice, age UK, love later life, Tavis House, 1-6 Tavistock Square, London WC1H 9NA. [Online]. Available: https://www.ageuk.org.uk/information-advice/coronavirus/staying-saf e-and-well-at-home/connecting-digital-devices-coronavirus/

[27] E. Tanya, "Troubling "technologies": Exploring the global learning xprize using the frameworks of skinner and foucault," Current Issues in Emerging eLearning, vol. 6, issue 1, article 1, 2019.

[28] A. Alenezi, "The role of e-learning materials in enhancing teaching and learning behaviors," International Journal of Information and Education Technology, vol. 10, no. 1, January 2020.

[29] A. S. Lestari, "Analysis of the implementation of e-learning in Stain Sultan Qaimuddin Kendari Southeast Sulawesi," International Journal of Information and Education Technology, vol. 6, no. 6, June 2016.

[30] K. Rajagopal et al., "Learner skills in open virtual mobility," Research in Learning Technology, vol. 28, 2020.
[31] J. Borup and M. A. Stevens, "Factors influencing teacher satisfaction at an online charter school," Journal of Online Learning Research, vol. 2 , no. 1, pp. 3-22, 2016.

[32] C. Li and F. Lalani, "The COVID-19 pandemic has changed education forever. This is how," World Economic Forum, 2020.

[33] T. Natasha, "First Middle East cases of coronavirus confirmed in the UAE CNBC.com," 2020.

[34] A. Rasheed. (2020). Coronavirus precaution: All UAE schools, universities implement e-learning until June 2020. Gulf News, Abu Dhabi UAE. [Online]. Available: https://gulfnews.com/uae/education/coronavirus-precaution-all-uae-sc hools-universities-implement-e-learning-until-june-2020-1.70313927

[35] P. A. Wang, "Assessment of asynchronous online discussions for a constructive online learning community," International Journal of Information and Education Technology, vol. 5, no. 8, August 2015.

[36] S. J. Sirkemaa, "Analysing e-learning and modern learning environments," International Journal of Information and Education Technology, vol. 4, no. 2, April 2014

[37] Course-Gate. (2020). Online classroom vs physical classroom! Which is better? Course-Gate: a world of education. [Online]. Available: https://coursegate.co.uk/online-classroom-vs-physical-classroom-whic h-is-better/

[38] C. Hewson and J. P. Charlton, "An investigation of the validity of course-based online assessment methods: The role of computer-related attitudes and assessment mode preferences," Journal of Computer Assisted Learning, Wiley Online Library, vol. 35, issue 1, February 2019, pp. 51-60, 2018

[39] J. L. Hwang, "Sustainability of e-learning environment: can social presence be enhanced by multimedia?" International Journal of Information and Education Technology, vol. 7, no. 4, April 2017.

[40] J. Elizondo-Garcia and K. Gallardo, "Peer feedback in learner-learner interaction practices. Mixed Methods Study on an xMOOC," The Electronic Journal of e-Learning, vol. 18, no. 2, pp. 122-135, 2020.

Copyright (C) 2021 by the authors. This is an open access article distributed under the Creative Commons Attribution License which permits unrestricted use, distribution, and reproduction in any medium, provided the original work is properly cited (CC BY 4.0).

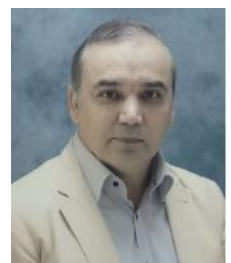

Liaqat Ali completed his $\mathrm{PhD}$, information systems, in 2008 from University of East London UK. He was associated with many international universities since 2005 and has supervised more than 125 postgraduate research theses. He is currently working in University of Science and Technology of Fujairah UAE. Dr Ali's principal research area for a number of years has been in the field of IS, e-accessibility and web development cyber-crimes and business information systems. His research activities covers E-accessibility, Web Development, Cyber-crimes and Computer Security, Business Information Systems and Management Information Systems. For further information on Dr Ali's profile, please visit https://liaqat22.wixsite.com/drali 